\title{
Iron Mobilization from Ferritin by Superoxide Derived from Stimulated Polymorphonuclear Leukocytes Possible Mechanism in Inflammation Diseases
}

Pieter Biemond, Henk G. van Eijk, Antonius J. G. Swaak, and Johan F. Koster

Departments of Biochemistry I and Chemical Pathology, Medical Faculty, Erasmus University, Rotterdam, The Netherlands;

Rheumatology Department, Daniël den Hoed Clinic, Rotterdam, The Netherlands

bstract. During inflammation, the superoxide anion $\left(\mathrm{O}_{2}^{-}\right)$and hydrogen peroxide $\left(\mathrm{H}_{2} \mathrm{O}_{2}\right)$ are produced by stimulated polymorphonuclear leukocytes and macrophages. The toxic effects of these reactive oxygen intermediates increase when traces of iron are present, because iron catalyzes the formation of the hydroxyl radical $\left(\mathrm{OH}^{\circ}\right)$. Partially saturated iron-binding proteins, such as transferrin and ferritin, are unable to catalyze $\mathrm{OH}^{\circ}$ formation in vitro. Mobilization of iron from these proteins is necessary for iron stimulation of $\mathrm{OH}^{*}$ formation. This paper reports that stimulated polymorphonuclear leukocytes mobilize iron from human and horse ferritin, but not from human transferrin. Iron release from ferritin depends on $\mathrm{O}_{2}^{-}$because it can be prevented by the addition of superoxide dismutase. Catalase and dimethylsulfoxide have no inhibitory effect on iron mobilization. The efficiency of the iron release increases at low levels of $\mathrm{O}_{2}^{-}$ production. Only $\mathrm{O}_{2}^{-}$produced by granulocytes is sufficient for iron mobilization, because solid potassium superoxide is also able to release iron from ferritin. We propose that this reaction may potentiate the formation of the $\mathrm{OH}^{\circ}$ radical in inflammatory states.

\section{Introduction}

During inflammation, stimulated polymorphonuclear leukocytes $(\mathrm{PMN})^{1}$ and macrophages produce large amounts of superoxide $\left(\mathrm{O}_{2}^{-}\right)$and hydrogen peroxide $\left(\mathrm{H}_{2} \mathrm{O}_{2}\right)(1)$. These products can be toxic by themselves, but their detrimental effects are strongly

Address correspondence to Dr. Koster, Department of Biochemistry I, Erasmus University.

Received for publication 21 September 1983 and in revised form 1 February 1984.

J. Clin. Invest.

(c) The American Society for Clinical Investigation, Inc. 0021-9738/84/06/1576/04 \$1.00

Volume 73, June 1984, 1576-1579 of the hydroxyl radical $\left(\mathrm{OH}^{\circ}\right)$ by the following overall reaction: $\mathrm{O}_{2}^{-}+\mathrm{H}_{2} \mathrm{O}_{2} \stackrel{\text { iron }}{\rightarrow} \mathrm{O}_{2}+\mathrm{OH}^{-}+\mathrm{OH}^{\circ}$. Nearly all the iron present in the body is located in haem-containing proteins and in ironbinding proteins such as transferrin, ferritin, lactoferrin, or in enzymes. In in vitro test systems, protein-bound iron is often unable to catalyze $\mathrm{OH}^{\circ}$ formation $(2,3,4)$. Iron-binding proteins are even able to inhibit oxygen-free radical destruction by binding of iron $(5,6)$.

The present investigations are focussed on the mobilization of iron from ferritin or transferrin by $\mathrm{O}_{2}^{-}$produced during inflammation. Subsequently, mobilized iron could catalyze $\mathrm{OH}^{*}$ formation. Ferritin is very important in the storage of iron, but the exact physiological mechanism for iron mobilization from ferritin is still unknown. Reduction of $\mathrm{Fe}^{3+}$ in the ferritin core to $\mathrm{Fe}^{2+}$ seems to be essential (7). Superoxide can act as a reductant able to reduce $\mathrm{Fe}^{3+}$ to $\mathrm{Fe}^{2+}$. In this study we were able to show that $\mathrm{O}_{2}^{-}$, derived from stimulated $\mathrm{PMN}$, is able to mobilize iron from ferritin. The relevance of this finding in relation to rheumatoid arthritis (RA) is discussed.

\section{Methods}

Reagents. Cadmium-free ferritin from horse spleen, $22 \%$ iron ( $50 \%$ saturated), catalase, cytochrome $c$, and superoxide dismutase (SOD) from bovine erythrocytes were obtained from C. F. Boehringer \& Sons, Mannheim, Federal Republic of Germany. Dimethylsulfoxide (DMSO) and 4,7 diphenyl-1,10-phenanthroline disulfonate acid sodium salt (bathophenanthroline) came from E. Merck, Darmstadt, Federal Republic of Germany. Human transferrin was from Behringwerke A.G., Marburg, Federal Republic of Germany; potassium superoxide $\left(\mathrm{KO}_{2}\right)$ came from Fluka A.G., Buchs, Switzerland; and Sephadex G-50 medium was from Pharmacia Fine Chemicals, Uppsala, Sweden. 4 $\beta$-Phorbol

1. Abbreviations used in this paper: DMSO, dimethylsulfoxide; $\mathrm{H}_{2} \mathrm{O}_{2}$, hydrogen peroxide; $\mathrm{OH}^{\circ}$, hydroxyl radical; PMA, $4 \beta$-phorbol $12 \beta$ myrisate $13 \alpha$-acetate; PMN, polymorphonuclear leukocytes; $\mathrm{KO}_{2}$, potassium superoxide; $\mathrm{O}_{2}^{-}$, superoxide; $\mathrm{SOD}$, superoxide dismutase.

2. Biemond, P., A. J. G. Swaak, and J. F. Koster. Arthritis Rheum. In press. 
$12 \beta$-myrisate $13 \alpha$-acetate (PMA) and horse spleen apoferritin were obtained from Sigma Chemical Co., St. Louis, MO. Sodium metrizoateficoll (Lymphoprep) came from Nyegaard \& Co., Oslo, Norway.

PMN leukocytes. PMN were isolated from defibrinated blood of healthy human volunteers by sodium metrizoate-ficoll centrifugation and by lysis of erythrocytes using a cold isotonic $\mathrm{NH}_{4} \mathrm{Cl}$ solution (8). The final cell suspension contained $>95 \%$ PMN. At least $95 \%$ of the cells were viable, based on the exclusion of trypan blue. PMN were suspended in a solution containing: $137 \mathrm{mM} \mathrm{NaCl}, 5.4 \mathrm{mM} \mathrm{KCl}, 0.7$ $\mathrm{mM} \mathrm{NaH}{ }_{2} \mathrm{PO}_{4}, 0.8 \mathrm{mM} \mathrm{MgSO}_{4}, 1.3 \mathrm{mM} \mathrm{CaCl}_{2}, 5.5 \mathrm{mM}$ glucose, 25 $\mathrm{mM}$ Tris ( $\mathrm{pH} 7.4$ at $37^{\circ} \mathrm{C}$ ), and $5 \mathrm{~g} / \mathrm{l}$ of bovine serum albumin. This solution was also used as incubation buffer.

Ferritin iron mobilization by $P M N$. The incubation mixture contained in final concentrations: $0.5-1.0 \times 10^{6} \mathrm{PMN} / \mathrm{ml}, 100 \mathrm{ng} \mathrm{PMA} / \mathrm{ml}, 0.25$ $\mathrm{mg} / \mathrm{ml}$ horse spleen ferritin, and $1 \mathrm{mM}$ bathophenanthroline. The incubation at $37^{\circ} \mathrm{C}$ was started by adding PMN. At different times, samples were drawn and placed on ice. The samples were centrifuged for $5 \mathrm{~min}$ at $20,000 \mathrm{~g}$ and the absorption at $530 \mathrm{~nm}$ was measured with the incubation buffer as reference. The amount of iron release was calculated from the increase in the absorption. The extinction coefficient of bathophenanthroline is $22,140 \mathrm{M}^{-1} \mathrm{~cm}^{-1}$ (9). The same incubations were performed with $0.25 \mathrm{mg} / \mathrm{ml}$ human ferritin, which was isolated from human liver according to Penders et al. (10), and with $3 \mathrm{mg} / \mathrm{ml}$ human transferrin, which was $60 \%$ saturated with iron. All the incubations were carried out in duplo. Gel filtration of the iron-binding proteins on Sephadex G-50 were carried out to exclude interference by nonproteinbound iron.

Efficiency of $\mathrm{O}_{2}^{-}$-dependent iron mobilization. Using the same batch of PMN, both the $\mathrm{O}_{2}^{-}$-production and the iron mobilization from horse spleen ferritin were measured at the same time. Iron release during 15 min was estimated as described above. $\mathrm{O}_{2}^{-}$production was measured with a mixture that contained $150 \mu \mathrm{M}$ cytochrome $c, 100 \mathrm{ng} / \mathrm{ml}$ PMA, and $0.034-1.34 \times 10^{6} \mathrm{PMN} / \mathrm{ml}$, using the same incubation buffer. The incubation at $37^{\circ} \mathrm{C}$ was started by addition of PMN. After $15 \mathrm{~min}$, the absorption at $550 \mathrm{~nm}$ was measured. The $\mathrm{O}_{2}^{-}$production was calculated from the increase of the absorption by using an extinction coefficient of $21,100 \mathrm{M}^{-1} \mathrm{~cm}^{-1}$ for cytochrome $c$. Control experiments showed that cytochrome $c$ reduction by stimulated PMN could be blocked completely by $13 \mu \mathrm{g} / \mathrm{ml}$ SOD.

Ferritin iron mobilization by $\mathrm{KO}_{2} .0 .25 \mathrm{mg} / \mathrm{ml}$ horse spleen ferritin and $1 \mathrm{mM}$ bathophenanthroline were added to the above mentioned buffer without bovine serum albumin (pH 7.4). The absorption at 530 $\mathrm{nm}$ was measured, using the buffer as reference. Solid $\mathrm{KO}_{2}$ was added, and after the oxygen bubbles disappeared the absorption was measured

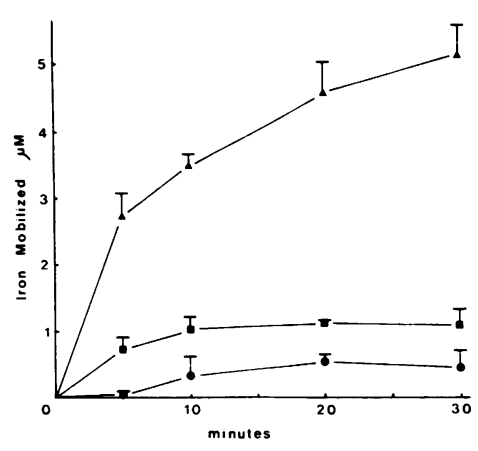

Figure 1. Iron mobilization from horse spleen ferritin by superoxide produced by stimulated PMN. The incubation mixture contained $0.25 \mathrm{mg} / \mathrm{ml}$ ferritin, 0.8 $\times 10^{6} \mathrm{PMN} / \mathrm{ml}$ and $1 \mathrm{mM}$ bathophenanthroline to measure $\mathrm{Fe}^{2+}$. Complete mixture (४); $100 \mu \mathrm{g} / \mathrm{ml}$ SOD added (๑); ferritin omitted ( $\square$ ). Mean and standard deviation of two incubations are shown.
Table I. Iron Mobilization from Human and Horse Ferritin and Transferrin by $\mathrm{O}_{2}^{-}$Produced by Stimulated $P M N$ and the Effect of SOD, Catalase, and DMSO

\begin{tabular}{lll}
\hline & & $\begin{array}{l}\text { Percentage of iron } \\
\text { mobilization } \\
\text { compared with the } \\
\text { complete system } \\
\text { without additions }\end{array}$ \\
\hline & $\begin{array}{l}\text { Iron mobilized } \\
\text { in } 30 \text { min }\end{array}$ & $\%$ \\
Horse spleen ferritin & $\mu M$ & \\
$\quad(0.25 \mathrm{mg} / \mathrm{ml}, n=9)$ & $5.1 \pm 0.4$ & 100 \\
Incubation at $0^{\circ} \mathrm{C}$ & & $0 \pm 3$ \\
Without ferritin & & $19 \pm 3$ \\
Apoferritin substituted for & & $16 \pm 5$ \\
$\quad$ ferritin & & $10 \pm 6$ \\
Without PMN & & $45 \pm 2$ \\
Addition SOD $(8.3 \mu \mathrm{g} / \mathrm{ml})$ & $25 \pm 10$ \\
Addition SOD $(33.3 \mu \mathrm{g} / \mathrm{ml})$ & & $120 \pm 9$ \\
Addition catalase $(1040 \mathrm{U} / \mathrm{ml})$ & & $102 \pm 7$ \\
Addition DMSO $(10 \mathrm{mM})$ & & 100 \\
Human liver ferritin $(0.25 \mathrm{mg} / \mathrm{ml})$ & $3.2 \pm 0.4$ & $46 \pm 4$ \\
Addition SOD $(33.3 \mu \mathrm{g} / \mathrm{ml})$ & & \\
Human transferrin $(3 \mathrm{mg} / \mathrm{ml})$ & $0.1 \pm 0.03$ & \\
Iron saturation $60 \%$ & & \\
& &
\end{tabular}

All incubations were carried out with three different PMN preparations; the mean \pm SD is shown. For each PMN preparation the incubations were performed in duplicate.

again. The addition of $\mathrm{KO}_{2}$ was repeated several times. At the end of this experiment the $\mathrm{pH}$ was slightly increased to 8.0.

\section{Results}

Fig. 1 shows that PMN, stimulated with PMA, are capable of mobilizing iron from horse spleen ferritin. The incubation mixture contained $0.25 \mathrm{mg} / \mathrm{ml}$ ferritin, which represented $980 \mu \mathrm{M}$ iron. After $30 \mathrm{~min}, 0.5 \%$ of the iron was mobilized. If the incubation was performed at $0^{\circ} \mathrm{C}$, or when no PMN were added, hardly any iron was mobilized (Table I). There was also no significant iron release following incubation in the absence of ferritin or with iron-free horse ferritin (apoferritin). After stimulation, $\mathrm{PMN}$ produce large amounts of $\mathrm{O}_{2}^{-}$and $\mathrm{H}_{2} \mathrm{O}_{2}$. It is known that $\mathrm{O}_{2}^{-}$can act as a reducing agent; therefore, $\mathrm{O}_{2}^{-}$could be responsible for the iron mobilization from ferritin. Addition of SOD resulted in an inhibition of iron mobilization, which gives strong evidence that $\mathrm{O}_{2}^{-}$is involved. Addition of catalase showed a small increase in iron release, which can be explained by prevention of reoxidation of $\mathrm{Fe}^{2+}$ by $\mathrm{H}_{2} \mathrm{O}_{2}$. DMSO, a scavenger of $\mathrm{OH}^{*}$ radicals, had no influence.

Similar results were obtained when human liver ferritin was added instead of horse spleen ferritin. The incubation mixture contained $980 \mu \mathrm{M}$ iron bound in ferritin. After $30 \mathrm{~min}, 0.3 \%$ of the iron was mobilized. Iron mobilization from human 
ferritin was also inhibited by the addition of SOD. No measurable amount of iron could be mobilized from human transferrin. The total amount of iron present in the incubation mixture was considerably lower in cases of transferrin compared with cases of ferritin. Also, by increasing the transferrin concentration five times, practically no iron could be mobilized. A further increase in concentration of transferrin was technically impossible. Sephadex G-50 gel filtrations of the iron-binding proteins were performed before the incubations to exclude interference by nonprotein-bound iron.

Theoretically, one mole of iron can be mobilized by one mole of $\mathrm{O}_{2}^{-}$. Therefore, the ratio of mobilized iron over total $\mathrm{O}_{2}^{-}$produced can be considered as a parameter for the efficiency by which $\mathrm{O}_{2}^{-}$is used for iron mobilization. This was tested by using varying amounts of PMN. Simultaneous measurements of $\mathrm{O}_{2}^{-}$production and iron release showed that the efficiency declined at higher $\mathrm{O}_{2}^{-}$production (Fig. 2).

During stimulation, proteases are also released. These proteases possibly destroy ferritin, thereby liberating the iron that is subsequently reduced by $\mathrm{O}_{2}^{-}$. Fig. 3 shows, however, that addition of grains of solid $\mathrm{KO}_{2}$ to ferritin caused mobilization of iron. This experiment showed that $\mathrm{O}_{2}^{-}$is capable of mobilizing iron from ferritin. $\mathrm{KO}_{2}$-induced iron mobilization ion could not be inhibited by SOD. This can be explained by the observation that at very high levels of $\mathrm{O}_{2}^{-}$, like in this experiment, spontaneous dismutation is much more important as SOD catalyzed dismutation (11).

\section{Discussion}

During inflammation, large amounts of $\mathrm{O}_{2}^{-}$and $\mathrm{H}_{2} \mathrm{O}_{2}$ are produced by stimulated PMN and macrophages (1). The destructive effects of these reactive oxygen intermediates are greatly enhanced by the presence of iron. This leads to the formation of the $\mathrm{OH}^{\circ}$ radical from $\mathrm{O}_{2}^{-}$and $\mathrm{H}_{2} \mathrm{O}_{2}$. In vivo, nearly all the iron is located in enzymes, haem-containing proteins, or in specific iron-binding proteins such as transferrin, ferritin, and lactoferrin.

Ferritin is the main protein in the storage of iron $(12,13)$. It consists of 24 polypeptide chains. There are two types of subunits (H and L) with molecular weights of 22,000 and 19,000, respectively. The polypeptide chains are arranged in a spherical protein shell with a central cavity. There are six channels through this shell. In one molecule of ferritin up to 4,500 iron atoms

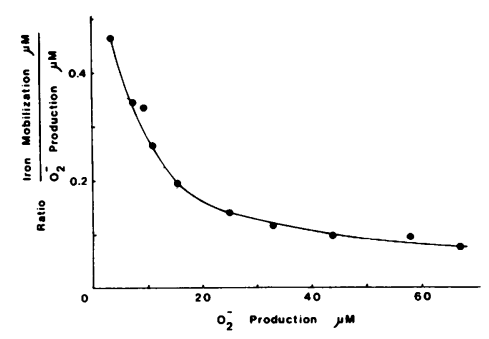

Figure 2. Efficiency of iron mobilization from horse spleen ferritin by $\mathrm{O}_{2}^{-}$produced by PMN. Simultaneous $\mathrm{O}_{2}^{-}$production and iron release from ferritin by stimulated PMN were measured. $\mathrm{O}_{2}^{-}$production was varied by using different amounts of PMN (0.034$\left.1.34 \times 10^{6} \mathrm{ml}\right)$. Incubation time was fixed at $15 \mathrm{~min}$.

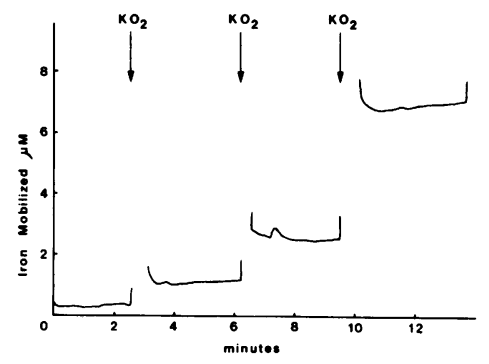

Figure 3. Iron mobilization from horse spleen ferritin by $\mathrm{KO}_{2}$. Assay mixture contained $0.25 \mathrm{mg} / \mathrm{ml}$ ferritin and $1 \mathrm{mM}$ bathophenanthroline. At indicated times some grains of $\mathrm{KO}_{2}$ were added.

can be stored. Iron is present in ferritin largely as ferric oxyhydroxide, together with some phosphate. Deposition of iron in ferritin requires that iron be present in the ferrous state; molecular oxygen is also used in the process. The exact mechanism is still unrevealed. The mechanism of iron mobilization is also unclear. A reducing substance is needed to form ferrous iron. In vivo reduced riboflavin mononucleotides possibly play this role. Subsequently, the ferrous iron must be complexed with a suitable iron chelator.

Many investigations in vitro showed that protein-bound iron does not catalyze $\mathrm{OH}^{\circ}$ formation (2-4). Furthermore, prevention of $\mathrm{OH}^{\circ}$ production by lactoferrin and transferrin was found to be due to the binding of free iron present in the test system ( 5 , $6)$. In contrast, other studies showed that iron-binding proteins were able to stimulate $\mathrm{OH}^{\circ}$ formation (14-17). In these studies, however, the iron-binding proteins were fully saturated with iron, which seldom occurs in vivo, or no saturation was mentioned. So, most probably in vivo, the iron-binding proteins, which are partially saturated with iron, are incapable of catalyzing the production of the very aggressive $\mathrm{OH}^{*}$ radical. Gutteridge et al. (4) reported the presence of a small amount of nonproteinbound iron in some extracellular fluids, for example synovial fluid. Until now, this interesting observation was not confirmed by others.

It is difficult to understand that "free iron" can exist in the presence of transferrin, only partially saturated with iron, because transferrin has a very high affinity for iron. The present study shows an alternative source of iron, which can catalyze $\mathrm{OH}^{\circ}$ formation. Stimulated PMN caused mobilization of iron from ferritin. The iron release could be blocked by SOD, but not by catalase or DMSO, indicating that $\mathrm{O}_{2}^{-}$was necessary in contrast to $\mathrm{H}_{2} \mathrm{O}_{2}$ and $\mathrm{OH}^{\circ}$. Catalase showed a small but reproducible increase in iron mobilization. This can be explained as follows: catalase inhibits oxidation of small amounts of free $\mathrm{Fe}^{2+}$ to $\mathrm{Fe}^{3+}$ by $\mathrm{H}_{2} \mathrm{O}_{2} \cdot \mathrm{Fe}^{3+}$ is unable to bind to bathophenanthroline, a known chelator, to estimate $\mathrm{Fe}^{2+}$.

The efficiency of iron mobilization by $\mathrm{O}_{2}^{-}$was dependent on the amount of $\mathrm{O}_{2}^{-}$produced. At a low level of $\mathrm{O}_{2}^{-}$production per time unit a relatively greater amount of iron was mobilized than at a higher level of $\mathrm{O}_{2}^{-}$production per time unit. Stimulated PMN also caused release of iron from human liver ferritin. Again the iron release was $\mathrm{O}_{2}^{-}$dependent, for it could be inhibited by SOD. $\mathrm{O}_{2}^{-}$was not able to release measurable amounts of iron from human transferrin.

Stimulated PMN not only produce $\mathrm{O}_{2}^{-}$and $\mathrm{H}_{2} \mathrm{O}_{2}$, but also produce proteolytic enzymes. It is possible that the proteolytic 
enzymes degrade the protein part of ferritin, and that $\mathrm{O}_{2}^{-}$subsequently reduces $\mathrm{Fe}^{3+}$ to $\mathrm{Fe}^{2+}$, which can bind to bathophenanthroline. Although it cannot be excluded that proteolytic enzymes play an additional role in the measured iron mobilization, it is shown that $\mathrm{O}_{2}^{-}$on its own is able to release iron from ferritin. Addition of solid $\mathrm{KO}_{2}$ to horse spleen ferritin resulted in a release of iron.

Iron release from ferritin is shown to be possible with xanthine and xanthine oxidase, a well known source of $\mathrm{O}_{2}^{-}(18$, 19). It is doubtful whether xanthine and xanthine oxidase mobilize iron from ferritin by formation of $\mathrm{O}_{2}^{-}$, because mobilization occurs much better when oxygen is absent and, in our knowledge, no literature data show that the release can be blocked by SOD. In preliminary investigations we were also able to release iron from ferritin by xanthine and xanthine oxidase, but it could not be blocked by SOD. Electrons are probably carried from the enzyme substrate complex to ferritin using a different carrier than $\mathrm{O}_{2}^{-}$.

The conclusion drawn is that stimulated PMN and macrophages will mobilize iron if ferritin is present by an $\mathrm{O}_{2}^{-}$-dependent mechanism. This iron can be used immediately for stimulating $\mathrm{OH}^{\circ}$ formation from $\mathrm{O}_{2}^{-}$and $\mathrm{H}_{2} \mathrm{O}_{2}$, which are produced by the same stimulated cells, before it will bind to transferrin.

The following pathophysiological consequences can be expected from the mobilization of iron from ferritin by stimulated PMN. There is a continuous flow of leukocytes to synovial fluid, predominantly PMN, reaching levels up to $7 \times 10^{7} / \mathrm{ml}$. The PMN phagocytose actively immune complexes and other material. These cell numbers are much higher than those used in the present in vitro study. Thus, a continuous production of considerable amounts of $\mathrm{O}_{2}^{-}$can be expected. Although the ferritin concentration in synovial fluid of RA patients is much lower than the concentration used in our system, the continuous $\mathrm{O}_{2}^{-}$production by the invading $\mathrm{PMN}$ possibly releases enough iron to catalyze the formation of $\mathrm{OH}^{\circ}$. It is worth mentioning that RA synovial fluid contains much higher concentrations of ferritin $(2.09 \pm 2.77 \mu \mathrm{g} / \mathrm{ml})$ than normal synovial fluid $(0.23 \pm 0.17$ $\mu \mathrm{g} / \mathrm{ml})^{2}(20)$. In the synovial membrane of RA patients the number of macrophages are increased and a large amount of ferritin is present (21); thus, iron mobilization can be expected. Iron release from ferritin by $\mathrm{O}_{2}^{-}$can also be important in other diseases when inflammatory cells are stimulated in the presence of ferritin. In haemochromatosis such a situation possibly occurs.

\section{Acknowledgments}

We wish to thank Dr. R. N. Lemon for correction of the English language and Mrs. E. M. W. van Zaal-de Korte for preparing the manuscript.

\section{References}

1. Babior, B. M., R. S. Kipnes, and J. T. Curnutte. 1973. Biological defense mechanism. The production by leukocytes of superoxide, a potent bactericidal agent. J. Clin. Invest. 52:741-744.

2. Halliwell, B. 1978. Superoxide-dependent formation of hydroxyl radicals in the presence of iron chelates. FEBS (Fed. Eur. Biochem. Soc.) Lett. 92:321-326.

3. Winterbourn, C. C. 1981 . Hydroxyl radical production in body fluids. Roles of metal ions, ascorbate and superoxide. Biochem. J. 198:125-131.

4. Gutteridge, J. M. C., D. A. Rowley, and B. Halliwell. 1981. Superoxide-dependent formation of hydroxyl radicals in the presence of iron salts. Detection of "free" iron in biological systems by using bleomycin-dependent degradation of DNA. Biochem. J. 199:263-265.

5. Stocks, J., J. M. C. Gutteridge, R. J. Sharp, and T. L. Dormandy. 1974. The inhibition of lipid autoxidation by human serum and its relation to serum proteins and $\alpha$-tocopherol. Clin. Sci. Mol. Med. 47:223233.

6. Gutteridge, J. M. C., S. K. Paterson, A. W. Segal, and B. Halliwell. 1981. Inhibition of lipid peroxidation by the iron-binding protein lactoferrin. Biochem. J. 199:259-261.

7. Jones, T., R. Spencer, and C. Walsh. 1978. Mechanism and kinetics of iron release from ferritin by dihydroflavins and dihydroflavin analogues. Biochemistry. 17:4011-4017.

8. Weening, R. S., D. Roos, and J. A. Loos. 1974. Oxygen consumption of phagocytizing cells in human leucocyte and granulocyte preparations: a comparative study. J. Lab. Clin. Med. 83:570-576.

9. Bothwell, T. H., R. W. Charlton, J. D. Cook, and C. A. Finch. 1979. Iron metabolism in man. Blackwell Scientific Publications Ltd., Oxford, England. 353-362.

10. Penders, T. J., H. H. de Rooij-Dijk, and B. Leijnse. 1968. Rapid isolation of ferritin by means of ultracentrifugation. Biochim. Biophys. Acta. 168:588-590.

11. Brawn, K., and I. Fridovich. 1980. Superoxide radical and superoxide dismutase: threat and defense. Acta Physiol. Scand. Suppl. 492:9-18.

12. Crichton, R. R. 1973. Structure and function of ferritin. Angew. Chem. Int. Ed. Engl. 12:57-65.

13. Harrison, P. M., S. H. Banyard, R. J. Hoare, S. M. Russell, and A. Treffry. 1977. The structure and function of ferritin. In Iron Metabolism. Ciba Foundation Symposium 51 (new series). Elsevier/Excerpta Medica/North-Holland, Amsterdam. 19-40.

14. McCord, J. M., and E. D. Day. 1978. Superoxide-dependent production of hydroxyl radical catalysed by iron-EDTA complex. FEBS (Fed. Eur. Biochem. Soc.) Lett. 86:139-142.

15. Ambruso, D. R., and R. B. Johnston. 1981. Lactoferrin enhances hydroxyl radical production by human neutrophils, neutrophil particulate fraction and an enzymatic generating system. J. Clin. Invest. 67:352360 .

16. Bannister, J. V., W. H. Bannister, H. A. O. Hill, and P. J. Thornalley. 1982. Enhanced production of hydroxyl radicals by the xanthine-xanthine oxidase reaction in the presence of lactoferrin. Biochim. Biophys. Acta. 715:116-120.

17. Motohashi, N., and I. Mori. 1983. Superoxide-dependent formation of hydroxyl radical catalysed by transferrin. FEBS (Fed. Eur. Biochem. Soc.) Lett. 157:197-199.

18. Mazur, A., S. Green, A. Saha, and A. Carleton. 1958. Mechanism of release of ferritin iron in vivo by xanthine oxidase. J. Clin. Invest. 37:1809-1817.

19. Duggan, D. E., and K. B. Streeter. 1973. Inhibition of ferritin reduction by pyrazolo $[3,4 \mathrm{~d}]$ pyrimidines. Arch. Biochem. Biophys. 156:66-70.

20. Blake, D. R., P. A. Bacon, E. J. Eastham, and K. Brigham. 1980. Synovial fluid ferritin in rheumatoid arthritis. Br. Med. J. 281:715-716.

21. Muirden, K. D. 1966. Ferritin in synovial cells in patients with rheumatoid arthritis. Ann. Rheum. Dis. 25:387-401. 